\title{
The Impact of Charismatic Leadership on the Organizational Performance in Travel Agencies
}

\author{
Shereen Gerges* Nehad M. Kamal* Hamida A. Mohammed* \\ *Faculty of Tourism and Hotels, University of Sadat City
}

\begin{abstract}
The aim of the study is to find out the impact of charismatic leadership behaviors on organizational performance. This explanatory study analyzes the impact of charismatic leadership on organizational performance for tourism managers in Egypt. This research investigates charismatic leadership behaviors (unconventional behavior, strategic visioning, sensitivity to the environment, and sensitivity to organizational members' needs)on organizational performance. Based on a quantitative study, 344 questionnaires were distributed. The result indicated that the charismatic leadership behaviors (unconventional behavior, strategic visioning, sensitivity to the environment, and sensitivity to organizational members' needs) impact on organizational performance positively.
\end{abstract}

Keywords: leadership, charismatic, organizational performance, tourism managers, Egyptian tourism companies.

\section{Introduction}

The goal of any organization is not only to survive, but also to sustain its existence by improving performance. In order to meet the needs of the highly competitive markets, organizations must continually increase performance (Arslan \& Staub, 2013). Prior literature suggests that role of leadership is critically important for achieving the performance of organizations (Boal \&Hooijberg, 2000; Peterson et al., 2003). However, the findings of prior studies about the role of leadership in increasing organizational performance are mixed. Some studies suggest that the role of leadership is critically important for an organization to achieve a high level of performance (Katz \& Kahn, 1978; Finkelstein \& Hambrick, 1996; Petersonet al., 2003).On the other hand, other studies suggest that the role of leadership is not important in achieving the organizational performance (Pfeffer \&Salancik 1978; Meindl et al., 1985).

There has been limited research that has specifically addressed the relationship betweencharismatic leadership behavior and organizational performance. The recent study will fill the gap by discussion the importance and impact of charismatic leadership for improving organizational performance in tourism sector. 
The main objective of the study is to find out the impact of charismatic leadership behaviors on organizational performance; the study will try to achieve the following specific objectives:

- To provide a brief overview of the leadership focusing specifically on the charismatic leadership.

- To determine the concepts of charismatic leadership behaviorsand organizational performance.

- To investigate the impact of charismatic leadership behavior on organizational performance in travel agencies.

\section{Literature review}

The literature review aims at giving the reader more deep insights into charismatic leadership and organizational performance. It is structured into four main sectors.The first part will consider the leadership, definitions, styles, and leadership in tourism. The second part will examine charismatic leadership, types, and dimensions. The third part will examine organizational performance, definitions, and dimensions. The last section will introduce the interrelationship between leadership and organizational performance, the impact of charismatic leadership on organizational performance.

\subsection{Leadership}

Leadership is lifeblood of any organization and its importance cannot be underestimated. Many authors have studied this phenomenon, but there is no conscious definition of what leadership is, no dominant paradigm for studying it, and little agreement regarding the best strategies for developing and exercising it (Bennis, 2007).Leadership is a kind of direction, which a person can give to a group of people under him in such a way that these will influence the behavior of another individual, or group (Akpala, 1998). Leadership is a reciprocal process of social influence, in which leaders and subordinates influence each other in order to achieve organizational goals (Ngodo, 2008). Leadership is a pattern of managerial behavior designed to integrate personal or organizational interest and effect, in pursuit of some objectives (Jeremy et al., 2012).

Leadership style refers to a kind of relationship whereby someone uses his ways and methods to make many people work together for a common task. In modern leadership theories, six leadership styles have been presented, including (A) charismatic leadership, (B) transactional leadership, (C) transformational leadership, (D) Autocratic leadership, ,(E) Bureaucratic leadership and (F) Democratic leadership (Rowe,2007).

Successful manager in tourism and hospitality as a leader should be a welleducated person with a high level of culture in various domains of life. The good knowledge and information provide the security in work, but they also make the manager appear attractive (Arnold, 2009). The overall appearance, behavior, good manners, way of speaking, eloquence, all contribute to the attractiveness of the manager in public (Elbanna \&Child, 2007). 
In addition, in small firms, managers are the key persons in making day-to-day decisions, and they are considered as the most imperative drivers of success in enabling firms to achieve their organizational goals (Pelham \& Lieb,2004; Arnold, 2009).This strengthens that the decisiveness of the manager is an essential contribution towards organizational success (Elbanna\&Child,2007).

\subsection{Charismatic Leadership}

Charismatic inspire those around them and have the power to modify the beliefs and values of followers in order to better align with the organization (Fiol et al., 1999). Characteristics that differentiate charismatic leaders from non-charismatic ones are seenby Rowe (2007) self-confidence, complete confidence in their judgment and ability, avision, idealized goal that proposes a future better than the status quo, strong convictions in thatvision, willingness to take high risks and engage in self-sacrifice to achieve their vision, behaviorout of the ordinary as well as radical change taking instead of caretakers of the status quo. Charisma is based on the aura of the exceptional/exemplary quality of a leader(Ehrhart\& Klein, 2001).

There are three types of Charismatic Leadership:-

1- Socialized charismatic leaders are good collaborators, with the capacity to listen to and engage followers in aligning goals and reaching a common vision (Gilbert \& Hyde, 1988; Blackshear, 2003).

2- Personalized Charismatic Leadershipis distinct in that they themselves or others consider them the sole possessor of authority, talent and direction. These types of leaders create a vision based on their own personal gain, rather than the group's benefit (Gilbert \& Hyde, 1988).

3- Dramaturgical Charismatic Leadership was defined by researchers Avolio and Gardner (1998) as a form of leadership that emulates the process actors go through to become great performers.

Studies of historical leaders reveal that charismatic leadership has both positive and negative consequences (Maccoby, 2004). Charismatic leaders tend to be able to see the gaps between what an organization delivers to its workers and what the workers need from the organization(Baker, 2007). They create visions that their supporters can readily see, and in return the supporters are motivated to contribute to a common goal (Wang et al., 2005).there is also a 'darkside' of charisma that can have a devastating impact on followers and the organization (Maccoby, 2004).

The self-confidence and optimism of the charismatic leader often conceals flaws and risks in the leader's vision. In fact, followers that closely identify with the leader's vision are less likely to give an objective appraisal of its strengths and weaknesses (Yukl, 2006). 
One of the well-researched models for studying the behaviors of charismatic leaders was developed by Conger and Kanungo (1994). This theory focuses on four behavioral factors considered to be exhibited by charismatic leaders: unconventional behavior, strategic visioning, sensitivity to the environment, and sensitivity to organizational members' needs. A leader uses these behaviors together as part of a process to bring about change in his or her organization.

1- Charismatic leaders engage in unconventional behavior in order to achieve organizational goals, they use nontraditional means to achieve organizational goals, and they often exhibits very unique behavior that surprises other members of the organization (Jaussi\& Dionne, 2003).

2 - Thestrategic vision that is articulated by a charismatic leader generally differs from the status quo (Conger \&Kanungo, 1998). Charismatic leaders may be viewed as agents of change who promise better opportunities and better outcomes to their followers(Conger \&Kanungo, 1998).

3- Charismatic leaders said to own an intensified sensitivity to the environment and carefully scan the patterns that would make them adjust their vision (Murphy \&Ensher, 2008).

4- Murphy and Ensher (2008) in their study illustrate that charismatic leaders were anticipated to display sensitivity to production team member requirements as part of the charismatic leadership process, by using effective techniques that developed joint liking and respect, and they spent time expressing individual concern for the requirements and feelings of the organization members.

\subsection{Organizational performance}

Organizational performance is similar to productivity as the effective and efficient use of resources to achieve outcomes, performance in the public sector has broader meaning than productivity, and it is guided and assessed by multiple, equally important standards of effectiveness, efficiency, and equity (Kearney \& Berman, 1999).Organizational performance was explained not to mean the performance of the single parts or units of the organization but the product of all interactions taking place in the organization (Stankard,2002).Organizational performance can be defined as "an ability of an organization to create employment, improve effectiveness, efficiency and quality of work life resulting in organizational growth and survival" (Baum \& Rowley, 2005:p.22).

\section{Dimensions of the organizational performance}

The organizational performance measurement methods presented by Venkatraman and Ramanujam (1986), such as the financial performance, business performance and organizational effectiveness, were adopted as the dimensions of the organizational performance.

Financial performance refers to the act of performing financial activity. In broader sense, financial performance refers to the degree to which financial objectives being or has been accomplished. It is the process of measuring the results of a firm's policies and operations in monetary terms (Zammuto, 1982). 
Business performance is the evaluation of all the efforts devoted to achieving the business goals (Akal, 1992).

Organizational effectiveness is a broader construct that captures organizational performance, but with grounding in organizational theory that entertains alternate performance goals (Cameron \& Whetten, 1983).

\subsection{The impact of charismatic leadership on organizational performance} Charismatic features of charismatic leadership have been defined as highly associated with positive level of organizational performance (Bass, 1985). In particular, the perception of leaders as charismatic was found to be associated with followers' performance and satisfaction (Shamir et al., 1993), with a high level of followers' perception of a shared and collective identity, and with the perception and expectations of successful group performance (Conger \&Kanungo, 1998; Conger et al., 2000).

Charismatic leadership had greater positive effects on organizational performance than did leader support or initiating structure behavior (House \&Aditya , 1997). Charismatic theory of leadership tries to explain how leaders get followers to exceed their own self-interest for the sake of an organization (Shamir et al., 1993). As charisma is a rare and complicated phenomenon that's hard to manipulate and often can be transitory (Trice \& Beyer, 1993), it is mostly noticed in organizations that are in crisis or survival zone. Here, leaders use charisma to empower the followers that is transforming them into much higher performers (Yukl, 1998).

\section{Charismatic leadership behavior and performance}

The leader's sensitivity to member needs and performance

The leader's sensitivity to member needs is clearly related to organizational performance. This sustains earlier research that used the leadership dimension of consideration, a similar factor. One explanation for this is that it committed to an organization where its leader was not attuned to his or her needs. Another might be that people feel they owe something to those who satisfy some of their needs (Conger, 1989).

\section{The strategic vision and performance}

Having a clear vision and articulating it also seems related to performance. It is likely that individual's self- select themselves into organizations that have similar values and leave organizations with dissimilar ones. An alternative view might be that as stronger emotions are communicated through the language used (e.g. high action verbs), the more likely the leader is to penetrate members' perceptual barriers. Members will in turn be more likely to notice the values held by the leaders. Once noticed, they may become more enthusiastic about the values (Nanus, 1992).

\section{The leader's sensitivity to the environment and performance}

Sensitivity to the environment is not significantly associated with organizational performance. The dimension of the assessment to the environment cannot specifically arouse the follower's positive leadership effects (Shamir et al., 1993). 


\section{Methodology}

This section presents a step by step procedure for the present research. The research structure of the research is based on research methodologies. A research methodology is the treatment that will be applied to the data collected. It outlines the research population, sample selection, pilot study, data collection and data analysis. In order to do this the following hypotheses were addressed:

The study aims to test the following hypotheses:

H1. Charismatic leadership unconventional behavior is positively related to the organizational performance.

H2. Charismatic leadership strategic vision and articulation is positively related to the organizational performance.

H3. Charismatic leadership sensitivity to the environment is positively related to the organizational performance.

H4. Charismatic leadership sensitivity to member needs is positively related to the organizational performance.

The full set of cases from which a sample is taken is called the population (1539) according to the statistics of the Egyptian Travel Agents Association (2014). In this research, the population is managers of tourism companies (Category A) in Great Cairo and Giza. A questionnaire was used in this study to collect data. The data of the study was collected from Egyptian tourism companies through distributing (400) questionnaire forms among tourism companies' managers and department managers. There were (344) questionnaire forms that were distributed correctly and successfully recollected with an approximate response rate of (86\%) of the total sample (400). The research sample was chosen as simple random. The questionnaire used in this study consists of three parts:

Part A: of the questionnaire measured the respondents' charismatic leadership behavior (Charisma) was measured using the 17-item of Conger and Kanungo charismatic leadership scale of environmental sensitivity, sensitivity to member needs, vision and articulation, and unconventional (Conger \&Kanungo, 1998).

Part B: measured organizational performance of the company by using (Choi \& Mueller, 1992) scale of financial performance, business performance, and organizational effectiveness. The scale was to ask respondents for the performance level of their companies for the last years, compared with different management performances of their competitors in the same industry.

Part C: of the questionnaire concerned with respondents' demographics. These questions included age, marital status, gender, work experience, education level and current position. This section was included at the end of the questionnaire because the researcher believes that respondents are less willing to complete questionnaires if these kinds of questions appear at the beginning of the questionnaire. 
This study uses Statistical Package for Social Sciences (SPSS) Version (19.0) to analyze the data.

\section{Reliability and validity}

Reliability of the measure in this study was first assessed using Cronbach's coefficient alpha. Cronbach's alpha is the most accepted formula for assessing reliability of a measurement with multi-point items. Before testing the research hypotheses, the researcher used (Alpha Cronbach's Scale)to ensure the measurement accuracy

Validity of the measure in this study is intrinsic validity

Validity $=\sqrt{\text { Reliability }}$

Table (1) Coefficient of reliability and validity of questionnaire

\begin{tabular}{|c|c|c|c|c|}
\hline & Instrument & $\begin{array}{l}\text { No. of } \\
\text { items }\end{array}$ & $\begin{array}{l}\text { Cronbach's } \\
\text { Alpha } \\
\text { Coefficient }\end{array}$ & Validity \\
\hline \multirow{4}{*}{ 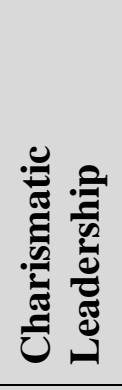 } & Unconventional behavior & 3 & 0.917 & .957 \\
\hline & $\begin{array}{lll}\begin{array}{l}\text { Strategic } \\
\text { articulation }\end{array} & \text { vision } & \text { and } \\
\end{array}$ & 7 & 0.898 & 947 \\
\hline & $\begin{array}{l}\text { Sensitivity to member } \\
\text { needs }\end{array}$ & 3 & 0.917 & .957 \\
\hline & $\begin{array}{l}\begin{array}{l}\text { Sensitivity } \\
\text { environment }\end{array}\end{array}$ & 4 & 0.911 & .954 \\
\hline \multirow{3}{*}{ 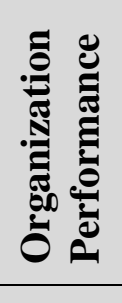 } & Financial performance & 4 & 0.910 & .954 \\
\hline & Business performance & 3 & 0.915 & .956 \\
\hline & $\begin{array}{l}\text { Organizational } \\
\text { effectiveness }\end{array}$ & 3 & 0.916 & .957 \\
\hline & Overall Total Scale & 27 & 0.922 & 0.96 \\
\hline
\end{tabular}

According to Pongsakornrungsilp (2011), researchers must be concerned with reliability and validity in order to ensure the quality and credibility of their research findings. Reliability coefficient of (0.7) or higher is considered "Acceptable" in most social science research situations (Tavakol\&Dennick, 2011).

The results of reliability analysis reported in table (1) revealed that all items-total correlations were above (0.70). Since most of the constructs of the questionnaire had a relatively accepted scores of reliability. 


\section{Result and discussion}

Table (2) descriptive statics of Personal information

\begin{tabular}{|l|c|c|}
\hline Gender & Frequency & Percentage \\
\hline Male & 212 & $61.6 \%$ \\
\hline Female & 132 & $38.4 \%$ \\
\hline Total & $\mathbf{3 4 4}$ & $\mathbf{1 0 0 \%}$ \\
\hline Age & Frequency & Percentage \\
\hline Less than 30 & 72 & $20.9 \%$ \\
\hline 30 to less than 40 & 98 & $28.5 \%$ \\
\hline 40 to less than 50 & 84 & $24.4 \%$ \\
\hline 50 years and more & 90 & $26.2 \%$ \\
\hline Total & $\mathbf{3 4 4}$ & $\mathbf{1 0 0 \%}$ \\
\hline Marital Status & Frequency & Percentage \\
\hline Single & 52 & $15.1 \%$ \\
\hline Married & 240 & $69.8 \%$ \\
\hline Other & 52 & $15.1 \%$ \\
\hline Total & $\mathbf{3 4 4}$ & $\mathbf{1 0 0 \%}$ \\
\hline Educational Level & Frequency & Percentage \\
\hline High School & 20 & 5.8 \\
\hline Bachelor & 260 & 75.6 \\
\hline Postgraduate studies & 64 & 18.6 \\
\hline Total & $\mathbf{3 4 4}$ & $\mathbf{1 0 0 \%}$ \\
\hline Position & Frequency & Percentage \\
\hline General manager & 62 & 18.0 \\
\hline Sales and Marketing Manager & 40 & 11.6 \\
\hline Operation Manager & 80 & $23.3 \%$ \\
\hline Reservation Manager & 38 & $11.0 \%$ \\
\hline Human Resources Manager & 60 & 17.4 \\
\hline Financial Manager & 48 & 14.0 \\
\hline Other & 16 & 4.7 \\
\hline Total & $\mathbf{3 4 4}$ & $\mathbf{1 0 0 \%}$ \\
\hline Work Experience & Frequency & Percentage \\
\hline Less than I year & 30 & 8.7 \\
\hline From 1 to less than 3 years & 76 & 22.1 \\
\hline From 3 to less than 6 years & 102 & 29.7 \\
\hline 6 years and more & $\mathbf{3 4 4}$ & 39.5 \\
\hline Total & & $\mathbf{1 0 0 \%}$ \\
\hline & & \\
\hline
\end{tabular}

The results of descriptive analysis of demographic variables of respondents of the study sample tabulated in table (2) were as follows:

Gender: It could be noticed that, the majority of the respondents were males and occupy the highest percentage of the sample. 
Age: As indicated in table (2) (20.9\%) of respondents are less than thirty years while (28.5\%) are between 30 and less than 40 years and (24.4\%) are between 40 and less than $50,(26.2 \%)$ are 50 years and more.

Marital Status: The obtained findings noticed that both single and married managers work in deferent departments in the tourism company. It is obvious that married managers occupy higher percentage representing (69.8\%) of the sample.

Education Level: it could be noticed that, the vast majority of the respondents (75.6\%) are college graduated, while post graduated represents (18.6\%) and only (5.8\%) of respondents had high school.

\section{Charismatic Leadership Constructs}

Table (3) Descriptive statistics of unconventional behavior construct

\begin{tabular}{|c|c|c|c|c|c|c|c|c|c|c|c|}
\hline \multirow[b]{2}{*}{ Statement } & \multicolumn{2}{|c|}{$\begin{array}{l}\text { Strongly } \\
\text { Disagree }\end{array}$} & \multicolumn{2}{|c|}{ Disagree } & \multicolumn{2}{|c|}{ Neutral } & \multicolumn{2}{|c|}{ Agree } & \multicolumn{2}{|c|}{$\begin{array}{l}\text { Strongly } \\
\text { Agree }\end{array}$} & \multirow{2}{*}{ Mean } \\
\hline & $\mathbf{F}$ & $\%$ & $\mathbf{F}$ & $\%$ & $\mathbf{F}$ & $\%$ & $\mathbf{F}$ & $\%$ & $\mathbf{F}$ & $\%$ & \\
\hline $\begin{array}{l}\text { I engage in unconventional } \\
\text { behavior in order to achieve } \\
\text { organizational goals }\end{array}$ & 36 & 10.5 & 44 & 12.8 & 82 & 23.8 & 116 & 33.7 & 66 & 19.2 & 3.38 \\
\hline $\begin{array}{l}\text { I use nontraditional means to } \\
\text { achieve organizational goals }\end{array}$ & 26 & 7.6 & 50 & 14.5 & 90 & 26.2 & 104 & 30.2 & 74 & 21.5 & 3.43 \\
\hline $\begin{array}{l}\text { Often exhibits very unique behavior } \\
\text { that surprises other members of the } \\
\text { organization }\end{array}$ & 30 & 8.7 & 62 & 18.0 & 66 & 19.2 & 108 & 31.4 & 78 & 22.7 & 3.41 \\
\hline \multicolumn{11}{|c|}{ Overall Mean } & 3.41 \\
\hline
\end{tabular}

According to the previous findings, the overall mean score for the statements of the unconventional behavior construct was (3.41). In other words, the managers in tourism companies were agree that the use of unconventional behavior was also important for many of these leaders as found in earlier research (Jaussi\& Dionne, 2003).

Table (4) Descriptive statistics of strategic vision and articulation construct

\begin{tabular}{|c|c|c|c|c|c|c|c|c|c|c|c|}
\hline \multirow{2}{*}{ Statement } & \multicolumn{2}{|c|}{$\begin{array}{l}\text { Strongly } \\
\text { Disagree }\end{array}$} & \multicolumn{2}{|c|}{ Disagree } & \multicolumn{2}{|c|}{ Neutral } & \multicolumn{2}{|c|}{ Agree } & \multicolumn{2}{|c|}{$\begin{array}{l}\text { Strongly } \\
\text { Agree }\end{array}$} & \multirow[b]{2}{*}{ Mean } \\
\hline & $\mathbf{F}$ & $\%$ & $\mathbf{F}$ & $\%$ & $\mathbf{F}$ & $\%$ & $\mathbf{F}$ & $\%$ & $\mathbf{F}$ & $\%$ & \\
\hline $\begin{array}{l}\text { I am able to motivate by articulating } \\
\text { effectively the importance of what } \\
\text { organizational members are doing }\end{array}$ & 38 & 11.0 & 34 & 9.9 & 70 & 20.3 & 120 & 34.9 & 82 & 23.8 & 3.50 \\
\hline I am exciting public speaker & 30 & 8.7 & 46 & 13.4 & 66 & 19.2 & 110 & 32.0 & 92 & 26.7 & 3.54 \\
\hline $\begin{array}{l}\text { I seize new opportunities in order to } \\
\text { achieve goals }\end{array}$ & 28 & 8.1 & 50 & 14.5 & 66 & 19.2 & 124 & 36.0 & 76 & 22.1 & 3.49 \\
\hline $\begin{array}{l}\text { I provide inspiring } \\
\text { organizational goals }\end{array}$ & 26 & 7.6 & 56 & 16.3 & 64 & 18.6 & 116 & 33.7 & 82 & 23.8 & 3.50 \\
\hline
\end{tabular}




\begin{tabular}{|l|l|l|l|l|l|l|l|l|l|l|l|}
\hline $\begin{array}{l}\text { I Consistently generate new ideas for the } \\
\text { future of the organization }\end{array}$ & 42 & 12.2 & 38 & 11.0 & 66 & 19.2 & 110 & 32.0 & 88 & 25.6 & 3.47 \\
\hline $\begin{array}{l}\text { I have vision; often brings up ideas about } \\
\text { possibilities for the future }\end{array}$ & 52 & 15.1 & 34 & 9.9 & 60 & 17.4 & 108 & 31.4 & 90 & 26.2 & 3.43 \\
\hline $\begin{array}{l}\text { I readily recognize new environmental } \\
\text { opportunities that may facilitate } \\
\text { achievement of organizational objectives }\end{array}$ & 26 & 7.6 & 56 & 16.3 & 70 & 20.3 & 94 & 27.3 & 98 & 28.5 & 3.52 \\
\hline Overall Mean
\end{tabular}

According to the previous findings, the overall mean score for the statements of the Strategic Vision and Articulation were (3.49). In other words, the managers in tourism companies were agree that the visioning process played an important role in setting the climate for the production. Managers reported utilizing different tactics for conveying vision and direction with different groups (e.g., actors, crew, and producers) based on physical distance, social distance, and task interaction frequency.

Table (5) Descriptive statistics of sensitivity to member needs dimension

\begin{tabular}{|c|c|c|c|c|c|c|c|c|c|c|c|}
\hline \multirow{2}{*}{ Statement } & \multicolumn{2}{|c|}{$\begin{array}{l}\text { Strongly } \\
\text { Disagree }\end{array}$} & \multicolumn{2}{|c|}{ Disagree } & \multicolumn{2}{|c|}{ Neutral } & \multicolumn{2}{|c|}{ Agree } & \multicolumn{2}{|c|}{$\begin{array}{l}\text { Strongly } \\
\text { agree }\end{array}$} & \multirow[t]{2}{*}{ Mean } \\
\hline & $\mathbf{F}$ & $\%$ & $\mathbf{F}$ & $\%$ & $\mathbf{F}$ & $\%$ & $\mathbf{F}$ & $\%$ & $\mathbf{F}$ & $\%$ & \\
\hline $\begin{array}{l}\text { I often express personal concern } \\
\text { for the needs and feelings of other } \\
\text { members of the organization }\end{array}$ & 32 & 9.3 & 48 & 14.0 & 70 & 20.3 & 114 & 33.1 & 80 & 23.3 & 3.47 \\
\hline $\begin{array}{l}\text { I Show sensitivity for the needs and } \\
\text { feelings of the other members in the } \\
\text { organization }\end{array}$ & 34 & 9.9 & 46 & 13.4 & 74 & 21.5 & 116 & 33.7 & 74 & 21.5 & 3.43 \\
\hline $\begin{array}{l}\text { I influence others by developing } \\
\text { mutual liking and respect }\end{array}$ & 32 & 9.3 & 52 & 15.1 & 62 & 18.0 & 122 & 35.5 & 76 & 22.1 & 3.45 \\
\hline Overall Mean & & & & & & & & & & & 3.45 \\
\hline
\end{tabular}

According to the previous findings, the overall mean score for the statements of the sensitivity to member needs were (3.45). In other words, the managers in tourism companies were agree that directors also gave many examples of how they demonstrated sensitivity to members' needs that matched the supportiveleader behaviors important for leading creative teams as found by Amabile et al. (2004).

Table (6) Descriptive statistics of sensitivity to the environment construct

\begin{tabular}{|c|c|c|c|c|c|c|c|c|c|c|c|}
\hline \multirow{2}{*}{ Statement } & \multicolumn{2}{|c|}{$\begin{array}{l}\text { Strongly } \\
\text { Disagree }\end{array}$} & \multicolumn{2}{|c|}{ Disagree } & \multicolumn{2}{|c|}{ Neutral } & \multicolumn{2}{|c|}{ Agree } & \multicolumn{2}{|c|}{$\begin{array}{l}\text { Strongly } \\
\text { Agree }\end{array}$} & \multirow{2}{*}{ Mean } \\
\hline & $\mathbf{F}$ & $\%$ & $\mathbf{F}$ & $\%$ & $\mathbf{F}$ & $\%$ & $\mathbf{F}$ & $\%$ & $\mathbf{F}$ & $\%$ & \\
\hline $\begin{array}{l}\text { I readily recognize constraints in the physical } \\
\text { environment (technological limitations, lack } \\
\text { of resources, etc.)that may stand in the way of } \\
\text { achieving organizational objectives }\end{array}$ & 40 & 11.6 & 46 & 13.4 & 70 & 20.3 & 98 & 28.5 & 90 & 26.2 & 3.44 \\
\hline
\end{tabular}




\begin{tabular}{|l|l|l|l|l|l|l|l|l|l|l|l|l|}
\hline $\begin{array}{l}\text { I readily recognize constraints in the } \\
\text { organization's social and cultural } \\
\text { environment (cultural norms, lack of } \\
\text { grassroots support, etc.) that may stand in the } \\
\text { way of achieving organizational objectives }\end{array}$ & 34 & 9.9 & 56 & 16.3 & 72 & 20.9 & 90 & 26.2 & 92 & 26.7 & 3.43 \\
\hline $\begin{array}{l}\text { I recognize the limitations of other members } \\
\text { of theorganization }\end{array}$ & 30 & 8.7 & 52 & 15.1 & 78 & 22.7 & 110 & 32.0 & 74 & 21.5 & 3.42 \\
\hline $\begin{array}{l}\text { I recognize the abilities and skills of other } \\
\text { members of the organization }\end{array}$ & 34 & 9.9 & 46 & 13.4 & 76 & 22.1 & 100 & 29.1 & 88 & 25.6 & 3.47 \\
\hline Overall Mean
\end{tabular}

According to the previous findings, the overall mean score for the statements of the Sensitivity to the Environment were (3.44). In other words, the managers in tourism companies were agree that leaders were keenly aware of the larger environment, however, it was not directly manifested in their leadership behavior, but instead impacted their technical/creative.

\section{Organizational Performance Constructs}

Table (7): Descriptive statistics of financial performance construct

\begin{tabular}{|c|c|c|c|c|c|c|c|c|c|c|c|}
\hline \multirow{2}{*}{ Statement } & \multicolumn{2}{|c|}{$\begin{array}{l}\text { Strongly } \\
\text { Disagree }\end{array}$} & \multicolumn{2}{|c|}{ Disagree } & \multicolumn{2}{|c|}{ Neutral } & \multicolumn{2}{|c|}{ Agree } & \multicolumn{2}{|c|}{$\begin{array}{l}\text { Strongly } \\
\text { Agree }\end{array}$} & \multirow{2}{*}{ Mean } \\
\hline & $\mathbf{F}$ & $\%$ & $\mathbf{F}$ & $\%$ & $\mathbf{F}$ & $\%$ & $\mathbf{F}$ & $\%$ & $\mathbf{F}$ & $\%$ & \\
\hline $\begin{array}{l}\text { The company's sales growth rate was } \\
\text { higher than that of the competitors } \\
\text { last year. }\end{array}$ & 24 & 7.0 & 64 & 18.6 & 54 & 15.7 & 124 & 36.0 & 78 & 22.7 & 3.48 \\
\hline $\begin{array}{l}\text { The company's after-tax net income } \\
\text { growth rate was higher than that of } \\
\text { the competitors last year. }\end{array}$ & 22 & 6.4 & 58 & 16.9 & 64 & 18.6 & 112 & 32.6 & 88 & 25.6 & 3.54 \\
\hline $\begin{array}{l}\text { The company's return on investment } \\
\text { was higher than that of the } \\
\text { competitors last year. }\end{array}$ & 24 & 7.0 & 68 & 19.8 & 54 & 15.7 & 110 & 32.0 & 88 & 25.6 & 3.49 \\
\hline $\begin{array}{l}\text { The company's employee } \\
\text { productivity was higher than that of } \\
\text { the competitors last year. }\end{array}$ & 28 & 8.1 & 52 & 15.1 & 68 & 19.8 & 112 & 32.6 & 84 & 24.4 & 3.50 \\
\hline \multicolumn{11}{|l|}{ Overall Mean } & 3.50 \\
\hline
\end{tabular}

According to the previous findings, the overall mean score for the statements of the financial performance were (3.50). In other words, the managers in tourism companies were agree that the degree to which financial objectives being or has been accomplished is highest in their tourism companies last year.

Previous results indicated that managers had a positive perception towards the financial performance. 
Table (8) Descriptive statistics of business performance construct

\begin{tabular}{|c|c|c|c|c|c|c|c|c|c|c|c|}
\hline \multirow[b]{2}{*}{ Statement } & \multicolumn{2}{|c|}{$\begin{array}{l}\text { Strongly } \\
\text { Disagree }\end{array}$} & \multicolumn{2}{|c|}{ Disagree } & \multicolumn{2}{|c|}{ Neutral } & \multicolumn{2}{|c|}{ Agree } & \multicolumn{2}{|c|}{$\begin{array}{l}\text { Strongly } \\
\text { Agree }\end{array}$} & \multirow{2}{*}{ Mean } \\
\hline & $\mathbf{F}$ & $\%$ & $\mathbf{F}$ & $\%$ & $\mathbf{F}$ & $\%$ & $\mathbf{F}$ & $\%$ & $\mathbf{F}$ & $\%$ & \\
\hline $\begin{array}{l}\text { The company's image is } \\
\text { better than that of the } \\
\text { competitors. }\end{array}$ & 28 & 8.1 & 62 & 18.0 & 54 & 15.7 & 106 & 30.8 & 94 & 27.3 & 3.51 \\
\hline $\begin{array}{l}\text { The company's attraction } \\
\text { to professionals was } \\
\text { higher than that of the } \\
\text { competitors. }\end{array}$ & 20 & 5.8 & 62 & 18.0 & 68 & 19.8 & 98 & 28.5 & 96 & 27.9 & 3.54 \\
\hline $\begin{array}{l}\text { The company's employee } \\
\text { morale is higher than that } \\
\text { of the competitors. }\end{array}$ & 20 & 5.8. & 62 & 18.0 & 62 & 18.0 & 116 & 33.7 & 84 & 24.4 & 3.52 \\
\hline Overall Mean & & & & & & & & & & & 3.52 \\
\hline
\end{tabular}

According to the previous findings, the overall mean score for the statements of the business performance were (3.52). In other words, the managers in tourism companies were agree that the business performance of their companies is highest last year.

Previous results indicated that managers had a positive perception towards the business performance.

Table (9): Descriptive statistics of organizational effectiveness construct

\begin{tabular}{|c|c|c|c|c|c|c|c|c|c|c|c|}
\hline \multirow[b]{2}{*}{ Statement } & \multicolumn{2}{|c|}{$\begin{array}{l}\text { Strongly } \\
\text { Disagree }\end{array}$} & \multicolumn{2}{|c|}{ Disagree } & \multicolumn{2}{|c|}{ Neutral } & \multicolumn{2}{|c|}{ Agree } & \multicolumn{2}{|c|}{$\begin{array}{l}\text { Strongly } \\
\text { Agree }\end{array}$} & \multirow{2}{*}{ Mean } \\
\hline & $\mathbf{F}$ & $\%$ & $\mathbf{F}$ & $\%$ & $\mathbf{F}$ & $\%$ & $\mathbf{F}$ & $\%$ & $\mathbf{F}$ & $\%$ & \\
\hline $\begin{array}{l}\text { The company's innovative } \\
\text { degree is higher than that } \\
\text { of the competitors. }\end{array}$ & 20 & 5.8 & 72 & 20.9 & 68 & 19.8 & 104 & 30.2 & 80 & 23.3 & 3.44 \\
\hline $\begin{array}{l}\text { The company's market } \\
\text { share is higher than that } \\
\text { of the competitors. }\end{array}$ & 24 & 7.0 & 64 & 18.6 & 72 & 20.9 & 104 & 30.2 & 80 & 23.3 & 3.44 \\
\hline $\begin{array}{l}\text { The company's staff } \\
\text { turnover was lower than } \\
\text { that of the competitors. }\end{array}$ & 28 & 8.1 & 56 & 16.3 & 72 & 20.9 & 100 & 29.1 & 88 & 25.6 & 3.47 \\
\hline Overall Mean & & & & & & & & & & & 3.45 \\
\hline
\end{tabular}




\section{Multiple Regression Analysis}

Table (13) The impact of unconventional behavior on organizational performance.

\begin{tabular}{|c|c|c|c|c|c|}
\hline $\mathbf{R}$ & R Square & $\begin{array}{l}\text { Adjusted-R } \\
\text { Souare }\end{array}$ & \multicolumn{3}{|l|}{ Std. Error of the Estimate } \\
\hline $0.884^{\mathrm{a}}$ & $\mathbf{0 . 7 8 1}$ & 0.779 & \multicolumn{3}{|l|}{5.503} \\
\hline \multicolumn{6}{|l|}{ ANOVA $^{\mathrm{a}}$} \\
\hline & $\begin{array}{l}\text { Sum } \\
\text { Squares }\end{array}$ & df & Mean Square & $\mathbf{F}$ & Sig. \\
\hline Regression & 36647.799 & 3 & 12215.933 & 403.326 & $0.000^{\mathrm{b}}$ \\
\hline \begin{tabular}{|l|} 
Residual \\
\end{tabular} & 10297.911 & 340 & 30.288 & & \\
\hline Total & 46945.709 & 343 & & & \\
\hline \multicolumn{6}{|l|}{ Coefficients $^{(\mathrm{a})}$} \\
\hline & \multicolumn{2}{|c|}{ UnstandardizedCoefficients } & StandardizedCoefficients & $\mathbf{T}$ & Sig. \\
\hline & B & Std. Error & Beta & & \\
\hline \begin{tabular}{|l} 
(constant) \\
\end{tabular} & 4.894 & 0.920 & & 5.321 & 0.000 \\
\hline $\begin{array}{l}\text { I engage in } \\
\text { unconventional behavior } \\
\text { in order to achieve } \\
\text { organizational goals }\end{array}$ & 1.183 & 0.625 & 0.190 & 2.901 & 0.004 \\
\hline $\begin{array}{l}\text { I use nontraditional means } \\
\text { to achieve organizational } \\
\text { goals }\end{array}$ & 3.318 & 0.586 & 0.339 & 5.661 & 0.000 \\
\hline $\begin{array}{l}\text { Often exhibits very unique } \\
\text { behavior that surprises } \\
\text { other members of the } \\
\text { organization }\end{array}$ & & & 0.395 & 7.227 & 0.000 \\
\hline
\end{tabular}

a Predictors: (Constant), (UB items).

\section{b Dependent Variable: (Organizational Performance).}

In connection with the first hypothesis, multiple regression analysis was conducted with organizational performance as the dependent variable and the three items of unconventional behavior as the independent variables. The adjusted $\mathrm{R}$ square value is (0.779) and $F$ value is (403.326) that is significant at $p=0.000$. These figures demonstrate that three items of unconventional behavior variable have significantly explained the $(77.9 \%$ of the variance in organizational performance (Table 13). Regression results show that engage in unconventional behavior $(\mathrm{t}=$ 2.901; $\mathrm{p}=0.004)$, using nontraditional means $(\mathrm{t}=5.661 ; \mathrm{p}=0.000)$, exhibits very unique behavior $(\mathrm{t}=7.227 ; \mathrm{p}=0.000)$ emerged as significant variables in explaining the variance in organizational performance. These values are significant at $1 \%$ significance level. 
Results of multiple regression analysis indicated that, the null hypothesis that said charismatic leadership unconventional behavior will not be positively impact on the organizational performance is rejected, and its alternative hypothesis that stated "charismatic leadership unconventional behavior willbe positively impacted to the organizational performance" is supported by my data set. This finding agrees with the work of Howell and Frost (1989), Fu-Jin et al. (2010), Obiwuru et al. (2011), and Jeremy et al. (2012) that unconventional behavior has significant effect on organizational performance.

\section{The Impact of Strategic Vision and Articulation on Organizational Performance}

Table (14) The impact of strategic vision and articulation on organizational performance.

\begin{tabular}{|c|c|c|c|c|c|c|}
\hline $\mathbf{R}$ & R Square & $\begin{array}{l}\text { Adjusted-R } \\
\text { Square }\end{array}$ & \multicolumn{4}{|c|}{ Std. Error of the Estimate } \\
\hline $0.915^{(\mathrm{a})}$ & 0.838 & 0.834 & \multicolumn{4}{|l|}{4.761} \\
\hline \multicolumn{7}{|l|}{$\mathrm{ANOVA}^{(\mathrm{a})}$} \\
\hline & \begin{tabular}{ll|} 
Sum & of \\
Squares &
\end{tabular} & df & $\begin{array}{l}\text { Mean } \\
\text { Square }\end{array}$ & $\mathbf{F}$ & \multicolumn{2}{|l|}{ Sig. } \\
\hline Regression & 39328.787 & 7 & 5618.398 & 403.326 & \multicolumn{2}{|l|}{$0.000^{(\mathbf{b})}$} \\
\hline Residual & 7616.922 & 336 & 22.669 & & & \\
\hline Total & 46945.709 & 343 & & & & \\
\hline \multicolumn{7}{|l|}{ Coefficients $^{(\text {a) }}$} \\
\hline & \multicolumn{2}{|c|}{$\begin{array}{l}\text { UnstandardizedCoefficient } \\
\text { s }\end{array}$} & \multirow{2}{*}{\multicolumn{2}{|c|}{$\begin{array}{l}\text { StandardizedCoefficie } \\
\text { nts } \\
\text { Beta }\end{array}$}} & \multirow[t]{2}{*}{$\mathbf{t}$} & \multirow[t]{2}{*}{ Sig. } \\
\hline & B & Std. Error & & & & \\
\hline (constant) & 4.406 & 0.842 & & & 5.235 & 0.000 \\
\hline $\begin{array}{l}\text { Able to motivate by } \\
\text { articulating effectively the } \\
\text { importance of what } \\
\text { organizational members } \\
\text { are doing }\end{array}$ & 1.175 & 0.583 & 0.127 & & 2.015 & 0.045 \\
\hline Exciting public speaker & 1.507 & 0.668 & 0.162 & & 2.255 & 0.025 \\
\hline Seize new opportunities & 1.553 & 0.618 & 0.161 & & 2.514 & 0.012 \\
\hline $\begin{array}{lr}\begin{array}{l}\text { Provide } \\
\text { strategic }\end{array} & \text { inspiring } \\
\text { organizational goals } & \text { and } \\
\end{array}$ & 1.604 & 0.537 & 0.168 & & 2.986 & 0.003 \\
\hline $\begin{array}{l}\text { Consistently generate new } \\
\text { ideas for the future }\end{array}$ & 1.188 & 0.595 & 0.133 & & 1.996 & 0.047 \\
\hline $\begin{array}{l}\text { I have vision; often brings } \\
\text { up ideas about } \\
\text { possibilities for the future }\end{array}$ & 2.023 & 0.620 & 0.237 & & 3.260 & 0.001 \\
\hline $\begin{array}{ll}\text { Readily recognize } & \text { new } \\
\text { environmental } & \\
\text { opportunities } & \\
\end{array}$ & $-.288-$ & 0.524 & $-0.31-$ & & $-0.549-$ & 0.583 \\
\hline
\end{tabular}

a Predictors: (Constant), (SVA items). 


\section{b Dependent Variable: (organizational performance).}

In connection with the second hypothesis, multiple regression analysis was conducted with organizational performance as the dependent variable and three items of strategic vision as the independent variables. The adjusted $\mathrm{R}$ square value is $(0.834)$ and $F$ value is (403.326) that is significant at $\mathrm{p}=0.000$. These figures demonstrate that seven items of strategic vision variable have significantly explained the $83.4 \%$ of the variance in organizational performance (Table 14). Regression results show that: able to motivate by articulating effectively the importance of what organizational members are doing $(\mathrm{t}=2.015 ; \mathrm{p}=0.045)$, exciting public speaker $(\mathrm{t}=2.255 ; \mathrm{p}=0.025)$, size new opportunities $(\mathrm{t}=2.514 ; \mathrm{p}$ $=0.012)$, provide inspiring strategic and organizational goals $(\mathrm{t}=2.986 ; \mathrm{p}=$ $0.003)$, consistently generate new ideas for the future $(t=1.996 ; p=0.047)$, have vision $(\mathrm{t}=3.260 ; \mathrm{p}=0.001)$ and readily recognize new environmental opportunities $(\mathrm{t}=0.549 ; \mathrm{p}=0.83) \quad$ emerged as significant variables in explaining the variance in organizational performance. These values are significant at $1 \%$ significance level.

Results of multiple regression analysis indicated that, the null hypothesis that said charismatic leadership strategic vision will not be positively impact on the organizational performance is rejected, and its alternative hypothesis that stated "charismatic leadership strategic vision willbe positively impacted to the organizational performance" is supported by my data set. This finding agrees with the study of Nanus (1992), Zhu et al. (2005), Howell and Hall-Merenda (1999), Kirkpatrick and Locke (1996) and Barling et al. (1996) that strategic vision has a significant effect on organizational performance.

Table (15) The Impact of Sensitivity to member needs' items on organizational performance

\begin{tabular}{|l|l|l|l|l|l|l|}
\hline R & R Square & $\begin{array}{l}\text { Adjusted-R } \\
\text { Square }\end{array}$ & \multicolumn{2}{l|}{ Std. Error of the Estimate } \\
\hline $0.870^{(a)}$ & 0.756 & 0.754 & 5.799 \\
\hline ANOVA $^{(a)}$ & $\begin{array}{l}\text { Sum of } \\
\text { Squares }\end{array}$ & df & Mean Square & F & Sig. \\
\hline & 35509.706 & 3 & 11836.398 & 351.909 & $0.000^{(\mathbf{b})}$ \\
\hline Regression & 11436.003 & 340 & 33.635 & & \\
\hline Residual & 46945.709 & 343 & & & \\
\hline Total &
\end{tabular}




\begin{tabular}{|c|c|c|c|c|c|}
\hline \multicolumn{5}{|l|}{ Coefficients $^{(\mathbf{a})}$} & \multirow{3}{*}{ Sig. } \\
\hline & \multicolumn{2}{|c|}{$\begin{array}{l}\text { Unstandardized } \\
\text { Coefficients }\end{array}$} & \multirow{2}{*}{\begin{tabular}{|l|}
$\begin{array}{l}\text { Standardized } \\
\text { Coefficients }\end{array}$ \\
Beta
\end{tabular}} & \multirow[t]{2}{*}{$\mathbf{t}$} & \\
\hline & B & Std. Error & & & \\
\hline (constant) & 5.759 & 0.952 & & 6.049 & 0.000 \\
\hline $\begin{array}{l}\text { I often express personal } \\
\text { concern for the needs } \\
\text { and feelings of other } \\
\text { members of the organization }\end{array}$ & 2.319 & 0.712 & 0.247 & 3.257 & 0.001 \\
\hline $\begin{array}{l}\text { Show sensitivity for the } \\
\text { needs and feelings of the } \\
\text { other members in the } \\
\text { organization }\end{array}$ & 2.639 & 0.680 & 0.280 & 3.883 & 0.000 \\
\hline $\begin{array}{l}\text { I influence others by } \\
\text { developing mutual liking and } \\
\text { respect }\end{array}$ & 3.497 & 0.614 & 0.373 & 5.698 & 0.000 \\
\hline
\end{tabular}

a Predictors: (Constant), (SMN items).

\section{b Dependent Variable: (organizational performance).}

In connection with the third hypothesis, multiple regression analysis was conducted with organizational performance as the dependent variable and three items of sensitivity to member needs as the independent variables. The adjusted $\mathrm{R}$ square value is $(0.754)$ and $F$ value is 351.909 that is significant at $p=0.000$. This table demonstrates that three items of sensitivity to member needs variable have significantly explained the $75.4 \%$ of the variance in organizational performance (Table 15). Regression results show that: express personal concern for the needs and feelings of other members of the organization $(t=3.257 ; p=0.001)$, show sensitivity for the needs and feelings of the other members in the organization $(\mathrm{t}=$ 3.883; $\mathrm{p}=0.000)$, influence others by developing mutual liking and respect $(\mathrm{t}=$ 5.698; $\mathrm{p}=0.000$ ) emerged as significant variables in explaining the variance in organizational performance. These values are significant at $1 \%$ significance level.

Results of multiple regression analysis indicated that, the null hypothesis that said charismatic leadership sensitivity to member needs will not be positively impact on the organizational performance is rejected, and its alternative hypothesis that stated "charismatic leadership sensitivity to member needs willbe positively impacted to the organizational performance".

This finding agrees with the study of Conger (1989), Fu-Jin et al. (2010), that sensitivity to member needs has a significant effect on organizational performance. 
Table (16) The Impact of Sensitivity to the environment' items on organizational performance

\begin{tabular}{|c|c|c|c|c|c|c|c|c|}
\hline $\mathbf{R}$ & R Square & $\begin{array}{l}\text { Adjusted-R } \\
\text { Square } \\
\end{array}$ & \multicolumn{6}{|c|}{ Std. Error of the Estimate } \\
\hline $0.899^{(\mathrm{a})}$ & 0.809 & 0.807 & \multicolumn{6}{|c|}{5.142} \\
\hline \multicolumn{9}{|l|}{ ANOVA $^{(a)}$} \\
\hline & $\begin{array}{l}\text { Sum of } \\
\text { Squares }\end{array}$ & df & \multicolumn{2}{|c|}{ Mean Square } & $\mathbf{F}$ & \multicolumn{3}{|l|}{ Sig. } \\
\hline Regression & 37980.238 & 4 & \multicolumn{2}{|c|}{9495.059} & 359.025 & \multicolumn{3}{|c|}{$0.000^{(\mathbf{b})}$} \\
\hline Residual & 8965.472 & 339 & \multicolumn{2}{|c|}{26.447} & & & & \\
\hline Total & 46945.709 & 343 & & & & & & \\
\hline \multicolumn{9}{|l|}{ Coefficients $^{(\mathbf{a})}$} \\
\hline & \multicolumn{3}{|c|}{ UnstandardizedCoefficients } & \multicolumn{3}{|c|}{ StandardizedCoefficients } & $\mathbf{t}$ & Sig. \\
\hline & $\mathbf{B}$ & \multicolumn{2}{|l|}{ Std. Error } & & & \\
\hline (constant) & 5.770 & \multicolumn{2}{|l|}{0.832} & \multicolumn{3}{|l|}{ Beta } & 6.935 & 0.000 \\
\hline $\begin{array}{l}\text { I readily recognize } \\
\text { constraints in the physical } \\
\text { environment }\end{array}$ & \begin{tabular}{l|l}
$e$ & \\
\end{tabular} & \multicolumn{2}{|l|}{0.585} & \multicolumn{3}{|l|}{0.283} & 4.301 & 0.000 \\
\hline \begin{tabular}{ll} 
I readily & \multicolumn{2}{c}{ recognize } \\
constraints & in \\
organization's social and \\
cultural environment
\end{tabular} & \begin{tabular}{l|l}
$e$ & \\
$e$ & 2.196 \\
$d$ & \\
\end{tabular} & \multicolumn{2}{|l|}{0.584} & \multicolumn{3}{|l|}{0.245} & 3.758 & 0.000 \\
\hline $\begin{array}{l}\text { I recognize the limitations } \\
\text { of other members }\end{array}$ & \begin{tabular}{l|l}
$\mathrm{S}$ & 1.510
\end{tabular} & \multicolumn{2}{|l|}{0.654} & \multicolumn{3}{|l|}{0.158} & 2.307 & 0.022 \\
\hline $\begin{array}{l}\text { I recognize the abilities and } \\
\text { skills of other members }\end{array}$ & \begin{tabular}{l|l}
$\mathrm{d}$ & 2.256 \\
\end{tabular} & \multicolumn{2}{|l|}{0.648} & \multicolumn{3}{|l|}{0.246} & 3.484 & 0.001 \\
\hline
\end{tabular}

\section{a Predictors: (Constant), (SE items).}

\section{b Dependent Variable: (organizational performance).}

Regression results show that: ready recognize constraints in the physical environment $(\mathrm{t}=4.301 ; \mathrm{p}=0.000)$, ready recognize constraints in the organization's social and cultural environment $(t=3.758 ; \mathrm{p}=0.000)$, recognize the limitations of the other members $(t=2.304 ; p=0.022)$, recognize the abilities and skills of other members emerged as significant variables in explaining the variance in organizational performance. These values are significant at $1 \%$ significance level.

Results of multiple regression analysis indicated that, the null hypothesis that said charismatic leadership sensitivity to environment will not be positively impact on the organizational performance is rejected, and its alternative hypothesis that stated "charismatic leadership sensitivity to environment willbe positively impacted to the organizational performance".

This finding agrees with the studies of Conger (1990) and Shamir et al. (1993) that showed sensitivity to environment has a significant effect on organizational performance 


\section{Conclusion and Recommendations}

This study has investigated the effect of charismatic leadership on organizational performance in tourism companies. Charismatic leadership was measured by four dimensions which are: unconventional behavior, strategic vision, sensitivity to member needs and sensitivity towards the environment). Meanwhile, the organizational performance was measured by three dimensions (financial performance, business performance and organizational effectiveness). The researcher found out that each dimension of the charismatic leadership has a strong positive effect on the organizational performance. Therefore, the first and second objectives aimed to provide a brief overview of the leadership focusing specifically on the charismatic leadership, and aimed to find out the concepts of charismatic leadership behavior and organizational performance.

The findings of the empirical study indicated that positive regression between charismatic leadership and the three dimensions of organizational performance were found. These regression do not differ much from correlations found in previous studies financial performance (Koene et al.,2002), Business performance (Avolioet al., 1998; Babcock Roberson \& Strickland, 2010; Bass \& Avolio, 1994; Kirkpatrick \& Locke,1996; Kouzes \& Posner, 1987; Waldman et al., 1990), and organizational effectiveness (Avolio et al., 1998).According to the results of multiple regression analysis for the relationship between charismatic leadership behavior (unconventional behavior, strategic vision, sensitivity to member needs, and sensitivity to the environment) and organizational performance found that each dimension of the charismatic leadership has a strong positive effect on the organizational performance.

Many studies agree with these results such as: unconventional behavior has significant effect on organizational performance (Howell \& Frost, 1989; Fu-Jin et al., 2010; Obiwuru et al., 2011; Jeremy et al. 2011). Strategic vision has significant effect on organizational performance (Nanus, 1992; Zhu et al., 2005; Howell\& Hall-Merenda ,1999 ; Kirkpatrick \& Locke,1996; Barling et al., 1996). Sensitivity to member needs has significant effect on organizational performance (Conger, 1989; Fu-Jin et al., 2010). Sensitivity to environment has significant effect on organizational performance (Conger, 1990; Shamir et al., 1993).According to the results of the research; charismatic leadership affects strongly organizational performance. Studies suggest that different behaviors of the manger affect organizational performance, including the preferred leadership style (Bycio, Hackett, \& Allen, 1995; Dutschke, 2003; Howell \& Avolio, 1993; Yukl, 1998).

Recommendations: Leaders may need to spend some time gradually increasing empowerment behaviors so as to encourage employees to begin to view empowerment as part of their role identities. It is also recommended that leaders can play an active role in encouraging creativity by elucidating to a follower the need for creative outcomes, and spelling out what are their organization's values, are. 
To develop the training programs for managerial level of the tourism activities to avoid bad managerial impact the self-confidence and optimism of the charismatic leader often conceals flaws and risks in the leader's vision. In fact, followers that closely identify with the leader's vision are less likely to give an objective appraisal of its strengths and weaknesses

\section{References}

- Akal, Z. (1992), Performance Measurement and Control in Business, MPM, No. 473. Ankara.

- Akpala, A. (1998) Igbo cultural factors that may bear on management and organizational performance in Nigeria. Business management topics, Enugu, Oktek Publishers.

- Amabile, T.M., Schatzel, E.A., Moneta, G.B., \& Kramer, S.J. (2004). Leader behaviors and work environment for creativity: Perceived leader support. The Leadership Quarterly. 15: 5-32.

- Arnold, T.J., (2009).Understanding retail managers' role in the sales of products and services. Journal of Retailing, 85(2):129-144.

- Arslan, A., and Staub, S. (2013). Theory X and Theory Y Type Leadership Behavior and its Impact on Organizational Performance: Small Business Owners in the Şishane Lighting and Chandelier District. Procedia-Social and Behavioral Sciences, 75: 102-111.

- Avolio, B. J. and Gardner, W. L. (1998). The charismatic relationship: A dramaturgical perspective, 23(1): 32-58.

- Avolio, B. J., Waldman, D. A., \& Einstein, W. O. (1998). Transformational leadership in a management game simulation: Impacting the bottom line. Group \& Organizational Studies. 13(1): 59-80.

- Babcock-Roberson, M. E., \& Strickland, O. J. (2010). The relationship between charismatic leadership, work engagement, and organizational citizen behaviors. The Journal of Psychology. 144(3): 313-326.

- Baker, S. (2007) Followership: The theoretical foundation of a contemporary construct. Journal of Leadership \& Organizational Studies, 14: 50-60

- Barling, J., Weber, T. and Kelloway, E.K. (1996) Effects of transformational leadership training on attitudinal \& financial outcomes: A field experiment. Journal of Applied Psychology, 81(6): 827-832.

- Bass, B. M. (1985). Leadership and performancebeyond expectations. New York: Free Press.

- Bass, B. M. and Avolio B. J. (1994). Improving organizational effectiveness through transformational leadership. Thousand Oaks, CA: Sage.

- Baum, J. şi and Rowley, T. (2005). Companion to Organizations: An Introducțion, Wiley-Blackwell (pp. 1-34).

- Bennis W. (2007). The challenge of leadership in the modern world: introduction to special issues. American Psychologist, 62(1): 2-5. 
- Blackshear, P.B. (2003). The followership continuum: A model for fine tuning the workforce. Public Manager, 32(2): 25.

- Boal, K. B., and Hooijberg, R. (2000). Strategic leadership research: Moving on. Leadership Quarterly, 11: 515-549.

- Cameron, K. S., \& Whetten, D. A. (1983). Organizational effectiveness: A comparison of multiple models pp: 261-277. New York: Academic Press, Inc.

- Choi, FD and Mueller, S (1992). What is Coefficient Alpha? An Examination of Theory and Application. Journal Applied Psychol., 78(2): 98-104.

- Conger, J. A. (1989). The charismatic leader: Behind the mystique of exceptional leadership. San Francisco, CA: Jossey-Bass.

- Conger, J. A. (1990). The dark side of leadership. Organizational Dynamics, 19: 44-55.

- Conger, J. A. and Kanungo, R. (1994).Charismatic leadershipin organizations: perceived behavioral attributes and theirmeasurement. Journal of Organizational Behavior, 15: 439-452.

- Conger, J. A., Kanungo, R. N., and Menon, S. T. (2000).Charismatic leadership and follower effects. Journal of Organizational Behavior, 21(7): 747-767.

- Conger,J. A. , and Kanungo , R. N. (1998). Charismatic leadership in organizations.Thousand Oaks, CA: Sage.

- Ehrhart, M. G., and Klein, K. J. (2001). Predicting followers' preferences for charismatic leadership: the influence of follower values and personality. Leadership Quarterly, 12(2): 153.

- Elbanna, S. and J. Child, (2007).Influences on strategic decision effectiveness: Development and test of an integrative model. Strategic Management Journal, 28(4): 431-453.

- Finkelstein, S., and Hambrick, D. C. (1996). Strategic leadership: Top executives and their effects on organizations. Minneapolis: West Publishing.

- Fiol, C.M., Harris, D. and House, R. (1999). Charismaticleadership: strategies for effecting social change. LeadershipQuarterly, 10: 449-482.

- Fu-Jin .W, Shieh .C and Tang . M. (2010). Effect of leadership style on organizational performance as viewed from human resources management strategy. African journal of business management, 4(18): 3924-3936.

- Gilbert, R.G., and Hyde, A.C. (1988). Followership and the federal worker. Public Administration Review, 48: 962-968.

- House, R. J., and Aditya, R. (1997). The social scientific study of leadership: Journal of Management, 23:409-474.

- Howell, J. M., and Frost, P. J. (1989). A laboratory study ofcharismatic leadership.Organizational Behavior and Human Decision Processes, 43: 243-269. 
- Howell, J.M. and Hall- Merenda, K.E.(1999). The ties that bind: The impact of leader-member exchange, transformational and transactional leadership, and distance on predicting follower performance. Journal of Applied Psychology, 84:680-694.

- Jaussi, K. S., and Dionne, S. D. (2003). Leading for creativity: The role of unconventional leader behavior. The Leadership Quarterly, 14(4): 475-498.

- Jeremy .M, Melinde .C \& Ciller V. (2012). Perceived leadership style and employee participation in a manufacturing company in the democratic republic of Congo, African journal of business management. 6(15): 53895398.

- Katz, D., and Kahn, R. L. (1978). The social psychology of organizations (2nd ed.). New York: Wiley.

- Kearney, R. C., and Berman, E. M. (Eds.) (1999). Public Sector Performance: Management, Motivation, and Measurement. Boulder CO: Westview Press.

- Kirkpatrick, S. A., and Locke, E. A. (1996). Direct and indirect effects of three corecharismatic leadership components on performance and attitudes. Journal of AppliedPsychology, 81: 36-51.

- Koene, A.S., Vogelaar, L.W., and Soeters, J.L. (2002). Leadership effects on organizational climate and financial performance : Local leadership effect in chain organizations, Leadership Quarterly, 13:193-215.

- Kouzes, J. M., \& Posner, B. Z. (1987). The leadership challenge: How to get extraordinary things done in organizations. San Francisco, CA: JosseyBass.

- Maccoby, M. (2004). The productive narcissist: The promise and peril of visionary leadership. New York: Broadway Books.

- Meindl, J. R., Ehrlich, S. B. and Dukerich, J. M. (1985). The romance of leadership. Administrative Science Quarterly, 30:78-102.

- Murphy, S. E., and Ensher, E. A. (2008). A qualitative analysis of charismatic leadership in creative teams: The case of television directors. The Leadership Quarterly, 19(3): 335-352.

- Nanus, B. (1992). Visionary leadership: Creating a compelling sense of direction for your organization. San Francisco, CA: Jossey-Bass.

- NgodoO.E ,(2008). Procedural justice and trust: The link in the transformational leadershiporganisational outcomes relationship. International Journal Leadership Studies. 4(1): 82-100.

- Pelham, A.M. and Lieb, P. (2004) Differences between presidents' and sales managers' perceptions of the industry environment and firm strategy in small industrial firms: relationship to performance satisfaction. Journal of Small Business Management,42(2):174-189.

- Peterson, R.S., Smith, D.B., Martorana, P.V., and Owens, P.D. (2003). The impact of chief executive officer personality on top management team 
dynamics: One mechanism by which leadership affects organizational performance. Journal of Applied Psychology, 88: 795-808.

- Pfeffer, J., and Salancik, G. R. (1978). The external control of organizations: A resource dependence perspective. New York: HarperCollins.

- Pongsakornrungsilp, P. (2011). "Energy consumption and the ecological footprint of tourism in an island destination: the case of KohSamui". Doctoral thesis, University of Exeter, 106-123.

- Rowe, W. G. (2007). Cases in Leadership. Thousand Oaks, CA: Sage Publications

- Shamir, B., House, R. J., and Arthur, M. B. (1993). The motivational effect of charismatic leadership: A self-concept based theory. Organization Science, 4: 577-594.

- Stankard, M. F. (2002). Management Systems and Organizational Performance: The Search for Excellence Beyond ISO9000. Westport, CT:Greenwood Publishing Group.

- Tavakol, M. and Dennick, R. (2011)."Making sense of Cronbach's alpha".International Journal of Medical Education, 1(2). 53-55.

- Trice, H. M., and Beyer, J. M. (1993). The cultures of work organizations. Englewood Cliffs, NJ: Prentice-Hall.

- Venkatraman N, Ramanujam V (1986). Measurement of business performance in Strategy research: a Comparison of approaches Academy of Management Review 11: 801-814.

- Waldman, D. A., Bass, B. M., \&Yammarino, F. J. (1990). Adding to contingent-reward behavior: The augmenting effect of charismatic leadership. Group \& Organization Studies, 15(4), 381-394.

- Wang, H., Law, K. S., Hackett, R. D., Wang, D., and Chen, Z. X. (2005). Leader-Member Exchange as a Mediator of the Relationship between Transformational Leadership and Followers' Performance and Organizational Citizenship Behavior. Academy of Management Journal, 48(3):420-432.

- Yukl, G. (1998). Leadership in organizations (4th ed.). Englewood Cliffs, NJ: Prentice Hall.

- Yukl, G. (2006). Leadership in organizations (6th ed.). Upper Saddle River, NJ: Prentice Education.

- Zammuto, R. F., (1982). Assessing Organizational Effectiveness, State University of New York Press, Albany, NY.

- Zhu, Q., Sarkis, J., \&Geng, Y. (2005). Green supply chain management in China: Pressures, practices and performance. International Journal of Operations and Production Management, 25: 449-468. 


\section{أثر القيادة الكاريزمية علي الأداء التنظيمي في شركات العياحة}

\section{الملخص العربي}

إن هدف أي منظمة ليس فقط هو أن تظل قائمة ولكن أيضاً أن تحافظ وتدعم هذا البقاء بتطوير

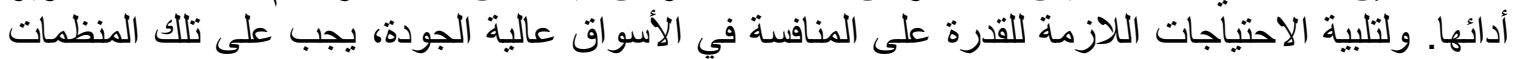

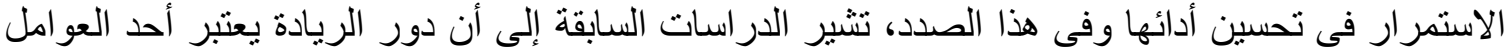

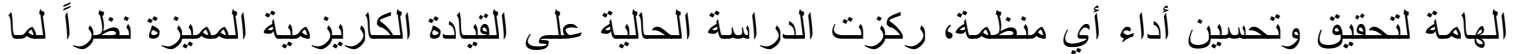

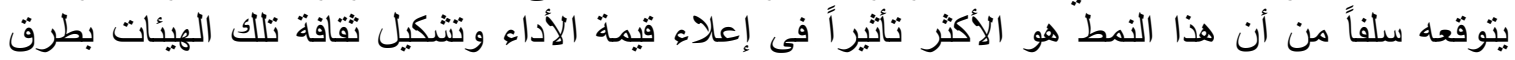

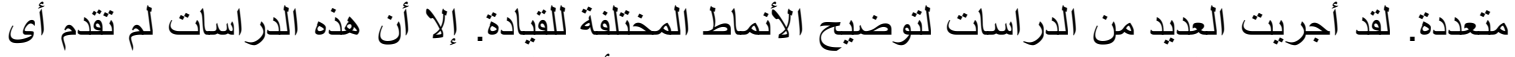

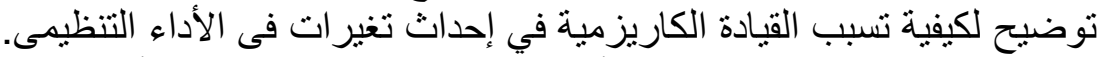

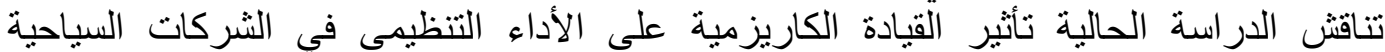
المصرية لكي يتم تحقيق أفضل أداء. يهدف هذا البحث إلى تحسين الأداء بتتجيعهم وتقديم أفضل النهاء النماذج

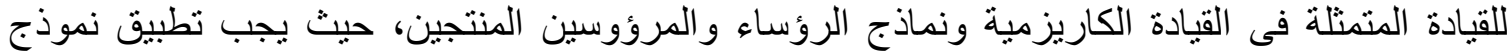
القيادة الكاريزمية بسهولة وبصورة جذابة حتى يحظى بالقبول 